\title{
An Deliberate Decentralized File Duplication Algorithm in Sharing System
}

\author{
I. Mary Linda, K.Shanmugapriya, Geetha C
}

\begin{abstract}
: of document is a technology that is used in peer to peer sharing networks. This technology is used to lessen center spots and enhance record utilization performance. Maximum modern record to fold back strategies mirror documents in every node else two give client and server data request direction. Those strategies may have less potency or with a cost of high overload. To fold back files in server, this aspect intensify duplicate hook price, so, research logicality however fabricate encumber nodes and cannot extensively lessen query route duration. File replication in consumer aspect ought to substantially lessen query course duration, however cannot guarantee excessive reproduction hit price to absolutely make use of replicas. Though facsimile on the edge of question route interpret troubles, as far as excessive fee of aloft to greater facsimile and produces less utilized facsimile. Peer networking communication is an architecture that occurs throughout an application that divides loads among peers. Neighbor's nodes are similarly classified efficacy contributors inside utility. Peer nodes are to shape seem-to-neighbor nodes in a network. Next node makes a element in their resources, consisting of processing strength, disk garage or community bandwidth, immediately ready to rest community members, no need for relevant to set in order through reliable hosts.
\end{abstract}

Keywords : Communication, Bandwidth, Reliable Hosts

\section{INTRODUCTION}

The big reputation of network and peer to peer nodes has turn out a remarkable spur to peer to peer report dispense systems, in which a document supplicant's questions is progressive to a record mainstay in a scattered approach. The structures can be utilized in demand for video carrier and collective virtual records application, wherein people devote documents which are to be had to others. A current big-scale description of HTTP traffic [1] has proven that greater than seventy five percent of traffic in the Internet is generated via peer to peer report allocation in the applications.

The take a look at as well indicates that the get right of entry to these documents is surprisingly recurring and out of true toward the maximum famous ones. In such position, if a server receives many requests at a time, it could grow to be overloaded and consequently cannot reply to the requests speedy .Therefore, noticeably famous files (i.e., warm files) could exhaust the bandwidth potential[2,3] of the system, main to low efficiency in record sharing .File imitation is an

Revised Manuscript Received on July 22, 2019.

Mary Linda I, Department of Computer science and Engineering, Bharath Institute of Higher Education and Research, Chennai, Tamilnadu, India. Email: catchlin.18@gmail.com

K.Shanmugapriya, Department of Computer science and Engineering, Bharath Institute of Higher Education and Research, Chennai, Tamilnadu, India. Email: shanmugapriyabiher@gmail.com

Geetha C, Department of Computer science and Engineering, Bharath Institute of Higher Education and Research, Chennai, Tamilnadu, India. Email: gitakannan.2010@gmail.com valuable technique to address the trouble of system overwork via distribute freight over facsimile nodes. It facilitates to

obtain elevated query competence by using lowering server reaction latency and research direction duration (i.e., the wide variety of moves in a hunt for route). A elevated valuable report imitation method gives better replica hit price. A facsimile hit takes place whilst a record demand is determined through a duplicate node in preference to the document owner. Facsimile hit charge denotes the share of the variety of file queries which might be resolved by way of reproduction nodes amongst full amount query[4,5]. Newly, plentiful document imitation strategies had been planned. The techniques can be in the main categorized into 3 classes mentioned by using Server Side, Client Side, and Path.

In a peer to peer document allocation device, teeming situations are routine all through blaze crowd else whilst a system nodes a searing report. If loads of host question for a warm organizer in server at time, server will be congested, foremost to not on time dossier question retort[8],[10],[12].

\section{RELATED WORK}

A better powerful report replication technique produces better duplicate hit fee. A facsimile hit occur while a record request is resolved with the aid of a duplicate node instead of the document proprietor[6]. facsimile hit charge signify the proportion of the quantity of document queries which are resolved by means of reproduction nodes amongst general queries. Just, several document imitation strategies were proposed. The strategies may be by and large confidential into three classes denote via ServerSide, ClientSide and Path. In a peer to peer record sharing device[13],[15],[17].

Eli Ben-Sasson et al. (2014), with a strong privacy warrant, builds a full ledger-based digital currency. In zero-knowledge Succinct Non-interactive Knowledge Arguments (zk-SNARKs), they lead in leverage novel developments. First, decentralized anonymous payment schemes (DAP schemes) are composed and constructed. A DAP scheme enables customers to pay the respective transaction confidentially directly to each other, shielding the source, destination and transferred quantity of the payment. Second, they are building Zerocash, a practical installation of the building of our DAP system. The outcome is that if transactions are less than $1 \mathrm{~KB}$ and take $6 \mathrm{~ms}$ to verify magnitude orders then they are more effective than the less anonymous Zerocoin and compete with simple Bitcoin[14],[16],[18].

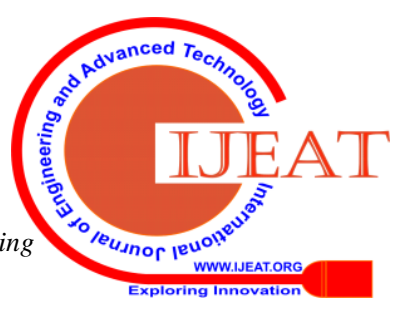


Pankaj Richhariya et al. (2012), the prospect of fraud detection is unsettled by the increase and fast escalation of ecommerce, and instances of economic fraud unified with it are also intensifying, leading to trillions of dollars being broken down every year globally. They given a extensive overview of various methods such as detection of credit card fraud, online auction fraud, detection of telecommunications fraud, and computer intrusion. The intrusion detection system's disadvantage is bad portability because the system and its set of rules must be specific to the monitoring setting[19],[21],[23].

Vikas Jayasree et al. (2017), estimates the danger of cash cleaning using the Bitmap Decision Tree (BIDT) method. Initially, learning from the Bitmap Index-based Decision Tree is used to cause the tree of understanding that helps to determine the danger of money laundering for a company and enhance scalability. The account in a table is numbered sequentially in a BIDT bitmap index with each key value, account number, and a used bitmap. Using the "select" query output, the BIDT algorithm subsequently applies count and bit-wise logical operations on AND. The outcome of the query corresponds precisely to the construction of a decision tree and more precisely to the assessment of the danger of adaptability in money cleaning job. The population frequencies are acquired for the root node, the primary account of the decision tree, merely by counting the complete amount of " 1 " in the bitmaps built on the element to look for money laundering and estimate the risk factor level. The experiment is performed on variables such as regulatory risk rate, false positive rate, and time to identify danger.The resulting analysis of the BIDT technique is compared with the existing Smart Card-based Security Framework (SCSF) and Multilayered Detection System (MDS) using Statlog German Credit Data[20],[22],[24].

\section{METHODS}

In preceding techniques, a document server keeps records of the duplicate hosts to manipulate the duplication and disseminates in order approximately novel reproduction set. The Server replicas the assets within the friends' nodes. Sometimes those nodes are overloaded. File replication is an powerful approach to address the hassle of system overwork via dispensing consignment greater than reproduction hosts. It allows to attain excessive question effectiveness by way of lowering system reaction delay and research lane extent. EAD adaptively adjusts the report reproduction nodes primarily based on recent question site visitors in a decentralized way. Traditional document replication techniques for peer to peer file giving out structures reflect documents seal to record proprietors, organizer requesters, or question route to launch the proprietors' consignment,[7,8] and for now, enhance the record question performance[25],[27],[29].

\section{MODULE DESCRIPTION}

\section{A. Peer Request}

In this module a System has to ask the connection to the Efficient peer (server)[9], the peer machine has to make a connection with any person Efficient peer for a communication

\section{B. Efficient Peer Response}

In this module the green peer has to send the reaction to the precise peer consistent with the capability of request.

\section{File Request}

In this module, the peer asks the (phrase report file or video documents) to the primary server i.E., (Efficient peer). The green peer test the particular statistics record inside the green peer database if observed ship to the peer (purchaser).

\section{Calculating Collision Node}

In this module, the server searches the collision node thru node ID for each peer (consumer) by way of the use of looking algorithm in peer to see community[26],[28],[30].

\section{E. Replicate the file to the collision node}

In this module, the servers replicate the high requested file to corresponding collision node.

\section{F. Peers download the file}

Peers download the document from collision node. The efficient peer sends the file to the peer (purchaser). The green peer creates a mutual connection to the customer.

\section{CONCLUSION}

Traditional report replication strategies for peer to peer document distribution system mirror documents lock to report owner, heading asking, or question direction to liberate the proprietors' load imply at same time as, enhance the document query performance. Replicating documents near the report proprietor may additionally overload the nodes inside the close proximity of the proprietor, and can't notably enhance question efficiency because facsimile nodes are near the owner. Duplicating files near to else within the report asking handiest bring profit when the petitioner or its close by nodes forever query in the record.

\section{REFERENCES}

1. Gowri Sankaran, B., Karthik, B. \& Vijayaragavan, S.P. 2019, "Weight ward change region plummeting change for square based image huffman coding", International Journal of Innovative Technology and Exploring Engineering, vol. 8, no. 10, pp. 4313-4316.

2. Gowri Sankaran, B., Karthik, B. \& Vijayaragavan, S.P. 2019, "Image compression utilizing wavelet transform", International Journal of Innovative Technology and Exploring Engineering, vol. 8, no. 10, pp. 4305-4308.

3. Kandavel, N. \& Kumaravel, A. 2019, "Offloading computation for efficient energy in mobile cloud computing", International Journal of Innovative Technology and Exploring Engineering, vol. 8, no. 10, pp. 4317-4320.

4. Vinoth, V.V. \& Kanniga, E. 2019, "Reversible data hiding in encrypting images-an system", International Journal of Engineering and Advanced Technology, vol. 8, no. 6, pp. 3051-3053.

5. Selvapriya, B. \& Raghu, B. 2019, "Pseudocoloring of medical images: A research", International Journal of Engineering and Advanced Technology, vol. 8, no. 6, pp. 3712-3716.

6. Senthil Kumar, K. \& Muthukumaravel, A. 2019, "Bi-objective constraint and hybrid optimizer for the test case prioritization", International Journal of Engineering and Advanced Technology, vol. 8 , no. 6 , pp. 3436-3448. 
7. Kavitha, G., Priya, N., Anuradha, C. \& Pothumani, S. 2019, "Read-write, peer-to-peer algorithms for the location-identity split", International Journal of Innovative Technology and Exploring Engineering, vol. 8, no. 9 Special Issue 3, pp. 445-447.

8. Kaliyamurthie, K.P., Michael, G., Anuratha, C. \& Sundaraj, B. 2019 "Certain improvements in alzheimer disease classification using novel fuzzy c means clustering for image segmentation", International Journal of Innovative Technology and Exploring Engineering, vol. 8, no. 9 Special Issue 3, pp. 599-604.

9. Kaliyamurthie, K.P., Sundarraj, B., Geo, A.V.A. \& Michael, G. 2019, "RIB: Analysis of I/O automata", International Journal of Innovative Technology and Exploring Engineering, vol. 8, no. 9 Special Issue 3, pp. 1019-1022

10. Velvizhi, R., Rajabhushanam, C. \& Vidhya, S.R.S. 2019, "Opinion mining for travel route recommendation using Social Media Networks (Twitter)", International Journal of Innovative Technology and Exploring Engineering, vol. 8, no. 9 Special Issue 3, pp. 508-512.

11. Kavitha, R., Sangeetha, S. \& Varghese, A.G. 2019, "Human activity patterns in big data for healthcare applications", International Journal of Innovative Technology and Exploring Engineering, vol. 8, no. 9 Special Issue 3, pp. 1101-1103.

12. Pothumani, S., Anandam, A.K., Sharma, N. \& Franklin, S. 2019, "Extended VEOT framework - Implemented in a smart boutique", International Journal of Innovative Technology and Exploring Engineering, vol. 8, no. 9 Special Issue 3, pp. 762-767.

13. Kaliyamurthie, K.P., Michael, G., Krishnan, R.M.V. \& Sundarraj, B. 2019, "Pseudorandom techniques for the internet", International Journal of Innovative Technology and Exploring Engineering, vol. 8, no. 9 Special Issue 3, pp. 915-918.

14. Aravindasamy, R., Jeffrin Rajan, M., Rama, A. \& Kavitha, P. 2019 "Deep learning provisions in the matlab: Focus on CNN facility", International Journal of Innovative Technology and Exploring Engineering, vol. 8, no. 9 Special Issue 3, pp. 990-994.

15. Theivasigamani, S., Linda, M. \& Amudha, S. 2019, "Object sensing and its identification \& motion sensing", International Journal of Innovative Technology and Exploring Engineering, vol. 8, no. 9 Special Issue 3, pp. 545-549.

16. Mary Linda, I., Vimala, D. \& Shanmuga Priya, K. 2019, "A methodology for the emulation of IPv4", International Journal of Innovative Technology and Exploring Engineering, vol. 8, no. 9 Special Issue 3, pp. 848-852.

17. Velvizhi, R., Priya, D.J., Vimala, D. \& Linda, I.M. 2019, "Increased routing algorithm for mobile adhoc networks", International Journal of Innovative Technology and Exploring Engineering, vol. 8, no. 9 Special Issue 3, pp. 1606-1608.

18. Sangeetha, S., Anuradha, C. \& Priya, N. 2019, "DNS in real world", International Journal of Innovative Technology and Exploring Engineering, vol. 8, no. 9 Special Issue 3, pp. 937-940.

19. Geetha, C., Vimala, D. \& Priya, K.S. 2019, "Constructing multi-processors and spreadsheets with SKIVE", International Journal of Innovative Technology and Exploring Engineering, vol. 8, no. 9 Special Issue 3, pp. 516-519.

20. Yugendhar, K., Sugumar, V. \& Kavitha, P. 2019, "A novel method of univac using fuzzy logic", International Journal of Innovative Technology and Exploring Engineering, vol. 8, no. 9 Special Issue 3, pp. 435-437.

21. Kaliyamurthie, K.P., Michael, G., Elankavi, R. \& Jijo, S.A. 2019, "Implementing aggregate-key for sharing data in cloud environment using cryptographic encryption", International Journal of Innovative Technology and Exploring Engineering, vol. 8, no. 9 Special Issue 3, pp. 957-959.

22. Jeffrin Rajan, M., Aravindasamy, R., Kavitha, P. \& Rama, A. 2019, "A novel method of object orientation variation in $\mathrm{C}++$ and java", International Journal of Innovative Technology and Exploring Engineering, vol. 8, no. 9 Special Issue 3, pp. 708-710.

23. Nayak, R., Dinesh, S. \& Thirunavukkarasu, S. 2019, "A novel method improvement of rapid miner for the data mining applications", International Journal of Innovative Technology and Exploring Engineering, vol. 8, no. 9 Special Issue 3, pp. 457-460.

24. Sivaraman, K., Krishnan, R.M.V., Sundarraj, B. \& Sri Gowthem, S. 2019, "Network failure detection and diagnosis by analyzing syslog and SNS data: Applying big data analysis to network operations", International Journal of Innovative Technology and Exploring Engineering, vol. 8, no. 9 Special Issue 3, pp. 883-887.

25. Vimala, D., Linda, I.M. \& Priya, K.S. 2019, "Decoupling online algorithms from erasure coding in DNS", International Journal of Innovative Technology and Exploring Engineering, vol. 8, no. 9 Special Issue 3, pp. 950-953.
26. Rama, A., Kumaravel, A. \& Nalini, C. 2019, "Preprocessing medical images for classification using deep learning techniques", International Journal of Innovative Technology and Exploring Engineering, vol. 8, no. 9 Special Issue 3, pp. 711-716.

27. Sangeetha, S., Srividhya, S.R., Anita Davamani, K. \& Amudha, S 2019, "A procedure for avoid overrun error in universal synchronous asynchronous receiver transmitter (usart) by utilizing dummy join and interrupt latency method", International Journal of Innovative Technology and Exploring Engineering, vol. 8, no. 9 Special Issue 3, pp. 657-660.

28. Aravindasamy, R., Jeyapriya, D., Sundarajan, B. \& Sangeetha, S. 2019, "Data duplication in cloud for optimal performance and security", International Journal of Innovative Technology and Exploring Engineering, vol. 8, no. 9 Special Issue 3, pp. 1156-1158.

29. Aravindasamy, R., Jeffrin Rajan, M., Sugumar, V. \& Kavitha, P. 2019 "A novel method on developing superblocks and the transistor using apodryal", International Journal of Innovative Technology and Exploring Engineering, vol. 8, no. 9 Special Issue 3, pp. 982-985.

30. Sasikumar, C.S. \& Kumaravel, A. 2019, "E-learning attributes selection through rough set theory and data mining", International Journal of Innovative Technology and Exploring Engineering, vol. 8, no. 10 , pp. 3920-3924

\section{AUTHORS PROFILE}

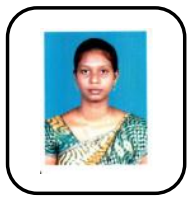

I.Mary Linda Assistant Professor, Department of Computer science and Engineering, Bharath Institute of Higher Education and Research, Chennai, India

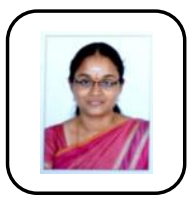

K.Shanmugapriya Assistant Professor, Department of Computer science and Engineering, Bharath Institute of Higher Education and Research, Chennai, India

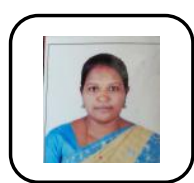

Geetha C Assistant Professor, Department of Computer science and Engineering, Bharath Institute of Higher Education and Research, Chennai, India 